\title{
PENGARUH ALAT PERAGA TIGA DIMENSI SISTEM PEREDARAN DARAH MANUSIA TERHADAP HASIL BELAJAR SISWA SMA
}

\author{
FAHRUDDIN ARFIANTO \\ Dosen Program Studi Agroteknologi Fakultas Pertanian dan Kehutanan \\ Universitas Muhammadiyah Palangkaraya
}

\begin{abstract}
Learning aids is very needed today. It is because nowadays, many aids in learning needed substantial funds in making them, for example a sculpture with plastic material and this will be an obstacle for schools located in remote areas. The aids can be simply made with just a second-hand things are widely available around us. Learning by using aids will greatly help students understand the concepts contained in learning materials. The aid in learning circulation of blood is very needed by students to understand directly the blood circulatory system in humans. The purpose of this study was to determine the effects of the three-dimensional visual aids in learning outcomes of material human blood circulatory system on high school students.

The method used in this study was pretest-posttest control group design, in this design, there were two groups of randomly selected, and then the groups given a pretest to determine the initial condition is the difference between the experimental group and the control group. The study was conducted in SMA Muhammadiyah 1 Palangka Raya. This study was conducted in period from April to May 2015. The sample of this study was the students of class XI in SMA Muhammadiyah 1 Palangka Raya in odd semestre. The study was taken two classes, namely as an experimental class and control class. The number of the students of control class was 29 students, and for experiments class was 21 students. The data collected by a test with the form of multiple choice questions to measure student learning outcomes. T-test data analysis by using SPSS software version 16.0

The result of this study showed that the three-dimensional aids in learning human blood circulatory system had significant effect on improving students' learning outcomes, based on t-test using SPSS software version 16.0. So, it can be concluded that the use of the three-dimensional aids in learning human circulatory system will improve the students' learning outcomes.
\end{abstract}

Keywords: three-dimensional aids, learning outcomes

\section{ABSTRAK}

Media belajar sangat diperlukan karena saat ini banyak media yang cara pembuatannya membutuhkan dana yang cukup besar misal patung dengan bahan plastik dan ini akan menjadi kendala sekolah-sekolah yang berada di daerah pelosok. Alat peraga dapat dibuat dengan sederhana hanya dengan barang-barang bekas yang banyak terdapat di sekitar kita. Belajar dengan menggunakan alat peraga akan sangat membantu siswa dalam memahami konsep-konsep yang terdapat dalam materi pembelajaran. Alat peraga untuk memberikan pembelajaran peredaran darah sangat diperlukan siswa untuk belajar memahami secara langsung sistem peredaran darah pada manusia. Tujuan penelitian ini adalah untuk mengetahui pengaruh alat peraga tiga dimensi sistem peredaran darah manusia terhadap hasil belajar siswa SMA.

Metode penelitian yang digunakan adalah pretest - postest Control group Design, dalam desain ini terdapat dua kelompok yang dipilih secara acak, kemudian diberi pretes untuk mengetahui keadaan awal adalah perbedaan antara kelompok eksperimen dan kelompok kontrol. Tempat penelitian adalah Sekolah Menengah Atas 1 Muhammadiyah Palangka Raya. Waktu penelitian bulan April - Mei 2015. Sampel penelitian adalah siswa SMA kelas XI semester satu diambil dua kelas yaitu sebagai kelas eksperimen dan kelas kontrol dengan jumlah siswa kelas kontrol 29 siswa, kelas eksperimen 21 siswa. Pengumpulan data dilakukan dengan tes dengan bentuk soal pilihan ganda untuk mengukur hasil belajar siswa. Analisa data Uji-t menggunakan software SPSS versi 16.0

Hasil penelitian menunjukkan bahwa alat peraga tiga dimensi sistem peredaran darah manusia berpengaruh signifikan terhadap peningkatan hasil belajar siswa, berdasarkan uji t dengan menggunakan software SPSS versi 16,0. Berdasarkan hasil penelitian dapat ditarik kesimpulan bahwa penggunaan alat peraga tiga dimensi sistem peredaran darah manusia akan meningkatkan hasil belajar.

Kata kunci : alat peraga tiga dimensi, hasil belajar 


\section{PENDAHULUAN}

\section{Latar Belakang}

Alat peraga sistem peredaran darah dewasa ini berkembang sangat pesat dan banyak ragamnya. Alat peraga atau media yang digunakan saat ini sangat banyak, baik berupa animasi maupun alat-alat peraga produksi pabrik. Alat peraga praktikum sistem peredaran darah sangat menunjang pada proses pembelajaran, namun karena adanya keterbatasan jumlah, variasi, dan kelengkapan alat peraga yang dimiliki oleh sekolah pada saat ini, maka pembelajaran belum bisa terlaksana dengan maksimal.

Media belajar sangat diperlukan karena saat ini banyak media yang cara pembuatannya membutuhkan dana yang cukup besar misal patung yang dibuat dengan bahan plastik dan ini akan menjadi kendala sekolah-sekolah yang berada di daerah pelosok. Alat Peraga dapat dibuat dengan sederhana hanya dengan barangbarang bekas yang banyak terdapat di sekitar kita. Belajar dengan menggunakan alat peraga akan sangat membantu siswa dalam memahami konsep-konsep yang terdapat dalam materi pembelajaran.

Alat peraga untuk memberikan pembelajaran peredaran darah sangat diperlukan siswa untuk belajar memahami secara langsung sistem peredaran darah pada manusia. Media atau alat peraga yang sering digunakan dalam pembelajaran sistem peredaran darah banyak menggunakan media animasi dan memerlukan listrik, kendala yang dihadapi adalah tidak adanya aliran listrik pada sekolah yang berada jauh dari perkotaan, sehingga pelajaran sistem peredaran darah tidak bisa dilaksanakan dengan baik.
Alat peraga tiga dimensi merupakan alat peraga yang memiliki panjang, lebar dan tinggi (Sugiyono, 2010). Alat peraga tiga dimensi dapat meningkatkan hasil belajar (Karmila, 2012), pada materi sistem peredaran darah manusia, penelitian untuk mengetahui hasil belajar sehingga diharapkan akan meningkat pula hasil belajar para siswa di SMA. Media yang digunakan untuk mengatasi masalah ini adalah dengan menggunakan alat peraga tiga dimensi yang bahannya terdiri dari gambar peredaran darah manusia, bingkai kayu ukuran $60 \times 80 \mathrm{~cm}$, selang plastik, botol, pompa minyak dan sumba merah. Kelebihan media tersebut ialah menggunakan bahan-bahan yang ada disekitar lingkungan kita, mudah membuatnya tanpa menggunakan listrik, sehingga dengan adanya alat peraga tiga dimensi tersebut tidak ada kendala lagi dalam mempraktekkan sistem peredaran darah. Alat peraga tiga dimensi akan meningkatkan hasil belajar menurut Karmila (2002).

Menurut Trianto (2010) tujuan melatih keterampilan proses sains pada pembelajaran IPA yaitu meningkatkan motivasi dan hasil belajar siswa karena dapat melatih siswa dipacu untuk berpartisipasi secara aktif dan efesien dalam belajar. Menurut Dimyati dan Mudjiono (2009) hasil belajar merupakan hasil dari suatu interaksi tindak belajar dan tindak mengajar, dari sisi guru tindakan mengajar diakhiri dengan proses evaluasi hasil belajar dari sisi siswa hasil belajar merupakan puncak proses belajar. Sistem peredaran pada manusia tersusun atas darah, pembuluh darah dan jantung sebagai pusat peredaran darah (Pratiwi $d k k$, 2007). 


\section{Tujuan Penelitian}

Tujuan Penelitian ini adalah untuk mengetahui pengaruh alat peraga tiga dimensi terhadap peningkatan hasil belajar materi sistem peredaran darah manusia pada siswa SMA

\section{METODE PENELITIAN}

\section{Tempat dan Waktu Penelitian}

Tempat penelitian adalah Sekolah Menengah Atas 1 Muhammadiyah Palangka Raya Jalan R.T.A. Milono Km 1.5 Palangka Raya. Waktu penelitian bulan April - Mei 2015.

\section{Desain Penelitian}

Desain yang digunakan adalah pretestpostest Control Group Design, dalam desain ini terdapat dua kelompok yang dipilih secara acak, kemudian diberi pretes untuk mengetahui keadaan awal adalah perbedaan antara kelompok eksperimen dan kelompok kontrol (Sugiyono, 2010).

\section{Instrumen Untuk Mengukur Hasil Belajar}

Instrumen penelitian berupa Tes objektif pilihan ganda, sejumlah 40 soal untuk mengetahui hasil belajar siswa setelah penerapan alat peraga tiga dimensi sistem peredaran darah . Instrumen ini berupa soal dalam bentuk pilihan ganda pada ranah kognitif dengan jenjang kemampuan $\mathrm{C}$, C2, C3, C4 dan C5. Instrumen ini sebelumnya sudah divalidasi oleh tim ahli. Data hasil pretes dipergunakan untuk mengukur pengetahuan awal siswa.

\section{Populasi dan Sampel Penelitian}

Populasi yang digunakan adalah siswa kelas XI IPA SMA Muhammadiyah 1 Palangkaraya sebanyak dua kelas dengan jumlah siswa 50 orang. Jumlah siswa yang menjadi sampel dalam penelitian ini sebanyak dua kelas yaitu kelas XI-IPA1 sebagai kelas eksperimen berjumlah 21 orang siswa dan kelas XI-IPA2 sebagai kelas kontrol berjumlah 29 orang siswa

\section{Teknik Pengumpulan Data}

Penelitian ini menggunakan dua kelas yaitu kelas kontrol dan kelas eksperimen yang masingmasing kelas diberi tes soal awal yaitu pretes dan tes lanjut yaitu postes, dengan jumlah siswa kelas kontrol berjumlah 29 dan kelas eksperimen berjumlah 21. Waktu yang digunakan yaitu bulan April 2014 pada siswa SMA Muhammadiyah 1 Palangka Raya. Tes pretes dipergunakan untuk mencari data awal dan postes digunakan untuk mencari data setelah dilakukan penerapan alat peraga tiga dimensi. Pengambilan data pada kelas kontrol berfungsi untuk membandingkan data pada kelas eksperimen setelah penerapan alat peraga tiga dimensi. Kelas kontrol menggunakan media gambar dan kelas eksperimen menggunakan alat peraga tiga dimensi sistem peredaran darah manusia

\section{Teknik Analisis Data}

Data hasil belajar diperoleh dari penelitian berupa nilai pretes dan postes, baik pada kelas kontrol dan kelas eksperimen dianalisis dengan uji t. Sebelum analisis uji $t$, data pretes dan postes dilakukan analisis terlebih dahulu untuk mengetahui peningkatan dengan menggunakan 
rumus N-Gain, kemudian nilai N-Gainnya yang digunakan untuk uji t.

Peningkatan hasil belajar setelah dilakukan penerapan alat peraga tiga dimensi digunakan $\mathrm{N}$ gain. Gain ternormalisasi (N Gain) diperoleh dengan cara menghitung selisih antara skor tes akhir dengan tes awal yang di bagi selisih antar skor maksimal dengan skor tes awal (Meltzer, 2002).

$$
\text { Gain (N Gain) }=\frac{\text { skor tes akhir }- \text { skor tes awal }}{\text { skor maksimal }- \text { skor tes awal }}
$$

Keterangan :

$$
\begin{array}{ll}
\mathrm{N}-\text { Gain }>0,70 & : \text { tinggi } \\
0,30 \leq \mathrm{N}-\text { Gain } \leq 0,70 & : \text { sedang } \\
<0,30 & : \text { rendah }
\end{array}
$$

\section{Pengujian Hipotesis Dengan Uji-t}

Untuk mengetahui pengaruh alat peraga tiga dimensi sistem peredaran darah manusia terhadap peningkatan hasil belajar dan keterampilan proses sains pada siswa SMA, maka dibandingkan dengan kelas kontrol dilakukan uji rata-rata (uji t) dengan menggunakan software SPSS versi 16.0 .

\section{HASIL DAN PEMBAHASAN}

\section{Data Hasil Belajar}

Data Hasil belajar siswa sebelum dan sesudah pembelajaran didapat dari perolehan rerata skor pretes dan rerata skor postes baik pada kelas kontrol maupun kelas eksperimen. Data rerata skor pretes dan rerata skor postes serta peningkatan $\mathrm{N}$-Gain yang dinormalisasikan dapat dilihat pada tabel 1 .
Berdasarkan tabel 1. Skor rata-rata pretes kelas eksperimen dengan nilai 14,24 lebih tinggi daripada skor rata-rata pretes kelas kontrol dengan nilai 16,03 . Skor rata-rata postes kelas eksperimen dengan nilai 32,43 lebih tinggi daripada skor rata-rata postes kelas kontrol dengan nilai 25,52 . Skor rata-rata $\mathrm{N}$-Gain pada kelas kontrol dengan nilai 0,40 (kategori sedang) lebih rendah daripada skor rata-rata N-Gain kelas eksperimen yaitu dengan nilai 0,71 (kategori tinggi). Dilihat dari data tersebut maka untuk peningkatan hasil belajar siswa kelas eksperimen lebih tinggi bila dibandingkan dengan kelas kontrol.

\section{Hasil Uji Hipotesis Hasil Belajar}

Pengujian hipotesis hasil belajar Siswa menggunakan uji-t dan menganalisanya dengan mempergunakan software SPSS versi 16,0. Hasil Pengujian dapat dilihat pada tabel 2.

Berdasarkan hasil tabel 2. dapat dilihat bahwa Uji perbedaan antara rerata skor pretes dan postes pada kelas eksperimen terdapat perbedaan yang signifikan. Data rerata hasil pretes dan postes kelas Kontrol menunjukkan perbedaan yang signifikan.

Uji perbedaan rerata postes kelas eksperimen dan rerata postes kelas kontrol menunjukkan perbedaan yang signifikan artinya bahwa nilai rerata postes kelas eksperimen pada materi sistem peredaran darah manusia lebih tinggi daripada rerata nilai postes kelas kontrol.

Uji perbedaan antara rerata N-Gain kelas eksperimen dan rerata $\mathrm{N}$-Gain kelas kontrol menunjukkan perbedaan yang signifikan yaitu nilai rerata $\mathrm{N}$-Gain peningkatan Hasil Belajar Siswa materi sistem peredaran darah manusia 
dengan alat peraga tiga dimensi lebih tinggi dari pada nilai rerata $\mathrm{N}$-Gain kelas kontrol atau kelas konvesional.

\section{Pembahasan}

Berdasarkan hasil analisis skor rerata postes hasil belajar siswa menunjukkan adanya perbedaan yang signifikan bahwa hasil belajar kelas yang menggunakan alat peraga tiga dimensi sistem peredaran darah manusia mempengaruhi siswa dalam meningkatkan pemahaman tentang sistem peredaran darah manusia. Alat peraga tiga dimensi sistem peredaran darah manusia mempunyai keunggulan diantaranya siswa akan melihat secara langsung darah akan mengalir dari jantung menuju vena pulmonari dan dialirkan ke seluruh tubuh manusia dan sebelum kembali ke jantung maka darah akan melewati paru-paru untuk mengambil oksigen yang nantinya akan dialirkan ke seluruh tubuh. Peredaran darah dari jantung menuju paru-paru dan kembali ke jantung disebut peredaran darah kecil.
Darah beredar dari jantung ke seluruh tubuh dan kembali ke jantung disebut peredaran darah besar (Omegawati dan Kusumawati, 2010). Kelas yang tidak menggunakan alat peraga tiga dimensi untuk hasil belajar siswa tidak ada kenaikan yang siginifikan ini menunjukkan bahwa siswa pada kelas tersebut pemahaman sistem peredaran darah manusia kurang dipahami secara sepenuhnya. Menggunakan alat peraga tiga dimensi akan meningkatkan hasil belajar (Sumiaty, 2009).

\section{KESIMPULAN DAN SARAN}

\section{Kesimpulan}

Berdasarkan hasil analisis data dan hasil pembahasan penelitian ini dapat ditarik kesimpulan yaitu pembelajaran biologi materi sistem peredaran darah manusia dengan menggunakan alat peraga tiga dimensi memberi peningkatan terhadap hasil belajar siswa dalam pemahaman materi tersebut. Siswa mampu

Tabel 1. Skor pretes, postes dan $\mathrm{N}$ - gain hasil belajar

\begin{tabular}{lcccccc}
\hline \multirow{2}{*}{ Hasil Belajar } & \multicolumn{3}{c}{ Kelas Eksperimen } & \multicolumn{3}{c}{ Kelas Kontrol } \\
\cline { 2 - 7 } & Pretes & Postes & N-gain & Pretes & Postes & $N$-gain \\
\hline Skor Maksimal & 19 & 36 & 0,86 & 19 & 30 & 0,58 \\
\hline Skor Minimum & 5 & 30 & 0,52 & 13 & 17 & 0.05 \\
\hline Skor rerata & 14,24 & 32,43 & 0,71 & 16,03 & 25,52 & 0,40 \\
\hline
\end{tabular}

Tabel 2. Data Uji - t Hasil Belajar Siswa

\begin{tabular}{|c|c|c|c|c|c|c|}
\hline Kelas & Data & Rerata & Std. Dev & ${ }^{\mathrm{t}}$ hitung & Sig. (2- tailed) & Keputusan \\
\hline Eksperimen & Postes & $32,43 \pm$ & 1,832 & \multirow{2}{*}{$-10,633$} & \multirow{2}{*}{0,000} & Berbeda \\
\hline Kontrol & Postes & $25,52 \pm$ & 2,760 & & & signifikan \\
\hline Eksperimen & N-Gain & $0,700 \pm$ & 0,089 & \multirow{2}{*}{$-10,015$} & \multirow{2}{*}{0,000} & Berbeda \\
\hline Kontrol & $\mathrm{N}$-Gain & $0,391 \pm$ & 0,123 & & & signifikan \\
\hline
\end{tabular}


memahami sistem peredaran darah manusia secara baik ini dibuktikan dengan data analisis hasil belajar yang berbeda sangat signifikan daripada kelas yang tidak menggunakan alat peraga tiga dimensi pada materi sistem peredaran darah manusia

\section{Saran}

Berdasarkan hasil analisis data dan hasil pembahasan penelitian penulis menyarankan :

1. Penelitian ini masih banyak kekurangan maka perlu diadakan penelitian lanjutan sehingga penelitian dengan alat peraga tiga dimensi akan lebih berkembang lagi.

2. Bagi Peneliti lain dapat membuat penelitian lanjutan dengan pembuatan alat peraga tiga dimensi yang tepat guna dan kalau bisa siswa dapat menciptakan sendiri alat peraga yang canggih, sehingga pemahaman akan materi sistem peredaran darah manusia semakin sempurna.

\section{DAFTAR PUSTAKA}

Arikunto, S. 2007, Dasar-dasar Evaluasi Pendidikan, Bumi Aksara. Yogyakarta.

Dahar, R.W. 1996. Teori-teori Belajar, Erlangga, Jakarta.

Dimyati dan Mudjiono, 2009, Belajar dan Pembelajaran, Rineka Cipta, Jakarta.

Hamalik, 2003, Proses Belajar Mengajar, Bumi Aksara, Jakarta.

Karmila, Penggunaan Alat Peraga Visual Tiga Dimensi Untuk Meningkatkan Hasil Belajar IPA Siswa Kelas IV SDN 2 Jatisela Tahun Ajaran 2012/2013,http://fkipunram.ac.id/ejurnal/ind ex.php/pgsd/article/view/146, diakses 5 Maret 2014.
Rustaman, N.Y., 2003, Strategi Belajar Mengajar Biologi, Jurusan Pendidikan Biologi FPMIPA UPI, Bandung.

Rustaman, N.Y, S. Dirdjosoemarto, S.A.Yudianto, M.N.Kusumastuti, Rochintaniawati., D. Achmad. 2005. Strategi Belajar Mengajar Biologi. Malang. UM Press : Malang.

Sudijono, 2001, Pengantar Evaluasi Pendidikan. PT Raja Grafindo Persada, Jakarta.

Sugiyono, 2010. Metode Penelitian Kuantitatif Kualitatif dan R\&D, Alfabeta

Sumiaty, 2009, Penggunaan Alat Peraga Tiga Dimensi Dalam Meningkatkan Hasil Belajar Matematika Pokok Bahasan Geometri Bangun Ruang, Biosainstifika jurnal biologi dan aplikasi biologi, Vol 4 No 1 Juli 2009, http://jurnal.upi.edu/biosainstifika/view/723/ penggunaan-alat-peraga- , diakses 22 maret 2015

Omegawati, W.H dan Kusumawati, R. 2010. Buku Panduan Pendidik Biologi Untuk SMA/MA. Intan Pariwara. Klaten

Pratiwi, D.A., Maryati, S., Srikini. Suharno dan Bambang. 2007. Biologi untuk SMA kelas XI. Erlangga. Jakarta.

Trianto. 2010. Model Pembelajaran Terpadu. Surabaya: Bumi Aksara. 